Marija Stanonik ZRC SAZU

Inštitut za slovensko

narodopisje

Ljubljana, Slovenija

marija.stanonik@zrc-sazu.si
DOI: ttps://doi.org/10.18485/slovenika.2018.4.1.8

UDK: 94:314.151.3-054.73(=163.6)(497.11)"1941/1945"(093.3)

94:314.151.3-054.73(=163.6)(430)"1941/1945"(093.3)

Strokovni članek

\title{
Na dobroti svet stoji: izkušnje slovenskih izgnancev med II. svetovno vojno v okupirano Srbijo in nacistično Nemčijo
}

Povzetek

Po navadi se iz vojnih dni obravnavajo samo težke in hude reči. Tokratna obravnava pa se posveča drobnim gestam dobrote in ljubeznivosti, ki so jih avtorji spominov doživeli kot otroci in jih zapisali sedemdeset let pozneje.

Ključne besede: II. svetovna vojna, izgnanci, otroci, Srbija, Nemčija - Tretji Rajh, Društvo izgnancev Slovenije 1941-1945

\section{Uvod}

O slovenskih izgnancih na jug, v razne predele prve Jugoslavije, ali na sever, v Nemški rajh, je bilo napisano veliko temeljitih zgodovinskih študij. Glede na to, da je bilo izseljevanje Slovencev osredotočeno na Štajersko, je največ spominov nanj s tega območja (Fabjančič 1959), kot da jih od drugod sploh ne bi bilo. Zato je zelo dobrodošla odločitev članov Društva izgnancev Slovenije 1941-1945 iz gorenjskih občin Gorenja vas - Poljane, Škofja Loka, Železniki in Žiri, da so se odločili popisati svoje vtise in spomine na prisilno potovanje in bivanje $v$ tujini, za katero niso mogli vedeti, ali ga bo kdaj konec. 


\section{Zgodovinski oris}

Slovenski izgnanci so bili prve množične žrtve fašizma in nacizma, a niso imeli statusa žrtve vojnega nasilja (Biček 2014, 14). Šele po združitvi Vzhodne in Zahodne Nemčije in v samostojni Sloveniji je bilo mogoče opozoriti na narodno in mednarodno plat te tragedije.

Med drugo svetovno vojno je bil izmed vseh okupiranih dežel delež izseljenega prebivalstva največji prav na Slovenskem. Iz krajev nekdanjega loškega gospostva je bilo izgnanih čez 500 posameznikov ali celotnih družin (Zadnik 2014, 7). Kot vzrok izgnanstva dosledno navajajo sodelovanje koga od domačih s partizani. Po koncu druge svetovne vojne ali celo tik pred tem se jih je velika večina vrnila na oropane, požgane domove ali celo zasedene domačije.

Raznarodovalna politika Tretjega rajha je temeljila na ideologiji nacionalsocialistične delavske stranke (NSDAP) in s tem že iz obdobja fevdalizma! nadaljevala nemške imperialistične težnje, da bi Velika Nemčija zajemala tudi vzhodne in jugovzhodne predele Evrope. ${ }^{1}$ (Košenina 2014, 16).

Dobro razvejena mreža vohunov je že od leta 1940 sestavljala ustrezne sezname in popisovala prebivalstvo, zapisovala razne podatke o slovenskih organizacijah in ustanovah; poleg splošnih podatkov se je morala predvsem osredotočati na zaupnike in sovražnike Tretjega rajha. Priprave za množični izgon Slovencev so nacisti začeli pripravljati že pred uvedbo civilne uprave. Nemška zasedbena uprava je imela podroben načrt raznarodovalnih ukrepov: izgnati rasno in tiste politično neustrezne osebe, predvsem zavedne Slovence, ki bi lahko zavirali ponemčevanje in krepitev že obstoječega nemštva (Košenina 2014,17).

Izganjanje so predvideli v treh valovih:

a) Vodilni sloj slovenskega izobraženstva in vse dotlej politično delujoče Slovence, predvsem znane zastopnike slovenskih političnih strank in organizacij v občinah in okrajnih mestih, učitelje, mlajše duhovnike in akademske poklice.

b) Vse prebivalce, ki so se na Gorenjsko preselili iz drugih delov tedanje Jugoslavije.

c) Vse prebivalce iz 20-kilometrskega južno-gorenjskega pasu ob meji z Ljubljano.

Popisovanje in ocenjevanje prebivalstva po političnih in narodnostnih lastnostih ter po Himmlerjevih smernicah neustreznih oseb, rasno preiskovanje in izvajanje deportacij so izvajali referati, ki so se med seboj usklajevali. Vsaka oseba je dobila politično oceno od 1 do 5 in rasno od I do IV. Na Gorenjskem sta bili dve zbirni taborišči: v prosto-

\footnotetext{
${ }^{1}$ Tukajšnje besede povzemajo uvod Saše Košenine, ki se v celoti opira na knjigo Toneta Ferenca Nacistična raznarodovalna politika v Sloveniji v letih 1941-1945 (Maribor : Obzorja, 1986).
} 
rih Škofijskih zavodov v Šentvidu pri Ljubljani in v Begunjah (Košenina 2014, 18).

Od predvidenih 220.000-260.000 za izgnanstvo predvidenih Slovencev so jih nacisti od doma pregnali čez 80.000 . Če bi nacisti vojno dobili, bi se večina Slovencev znašla v vzhodni Evropi. Največ, kar 45.000 jih je bilo izgnanih v Nemčijo, na Hrvaško 10.000, v Srbijo okrog 7.500. Okrog 17.000 jih je pred izgonom pobegnilo na območje, ki ga je okupirala Italija.

Med izgnanimi Slovenci je bilo tudi več kot 20.000 slovenskih otrok, mlajših od deset let (Biček 2014, 12). Zgodovinopisje doslej še ni registriralo, da v nobeni vojni poprej niso bili otroci žrtve tolikšnega nasilja in tako kruto in neposredno prizadeti kot $v$ drugi svetovni vojni. Veliko se je govorilo o 600 ukradenih otrocih, »nič pa o več kot 20.000 slovenskih otrocih do desetega leta starosti, ki jih je nemški okupator nasilno odgnal v nemška izgnanska taborišča po vseh pokrajinah tretjega rajha« (Biček 2014, 12).

\section{Zbiranje spominov}

Članek se gradivsko opira na spomine, ki so nastali po dobrih sedemdesetih letih, na čas, ko so morali njihovi avtorji kot otroci - od šestmesečne dojenčice do tistih na pragu odraslosti - skupaj s svojimi starši prisilno na hitro zapustiti rojstni dom, domačijo in domovino. Zato so tukajšnji spomini izgnancev predvsem otroški, danes pa so njihovi avtorji seveda lahko že zelo $v$ letih, saj je od je časa izgnanstva poteklo že blizu sedemdeset ali več let. Napisali so jih namreč izgnanci, begunci in pregnanci iz občin Gorenja vas - Poljane, Škofja Loka, Železniki in Žiri, ki so člani Društva izgnancev Slovenije 1941-1945. ${ }^{2}$

Spomine so začeli zbirati leta 2012, po dvajsetih letih obstoja škofjeloške območne organizacije Društva izgnancev (Zadnik 1914). Od 203 članov območne organizacije s sedežem v Škofji Loki je se jih je osemdeset, tj. slabih $40 \%$, odzvalo na pobudo, da bi zapisali spomine na hudi čas druge svetovne vojne. Kar devetinšestdeset prispevkov se nanaša na izgnanstvo $v$ Tretji rajh in enajst na jug, praviloma $v$ Srbijo. Bistvena razlika med severom in jugom je $\vee$ tem, da so $\vee$ Nemčiji izgnanci doživljali večji pritisk, ker so se morali $\vee$ vnaprej določenih »lagerjih« popolnoma podrediti bolj ali manj vojaški disciplini, medtem ko so bili izgnanci na jug prepuščeni sami sebi in prebivalcem $v$ okolju, kjer so se znašli.

Doživljali so veliko hudega, grdega, trpkega, toda tudi kaj dobrega, bodisi $v$ rosnem otroštvu na poti od doma $v$ neznano, ali že $v$ taboriščih, česar se nekdanji otroci še kot zreli ljudje, če ne že starci/starke

\footnotetext{
${ }^{2}$ Ne gre samo za prebivalce iz omenjenih občin, temveč tudi za prebivalce iz drugih krajev, ki so se po drugi svetovni vojni preselili v omenjene občine.
} 
hvaležno spominjajo. Namen tukajšnjega članka je izbrati iz presušene trave $^{3}$ te drobne spominske cvetke $v$ šopek dobrote.

$\checkmark$ hudem času je prav dobrota $v$ različnih oblikah vsaj za hip olajšala položaj posameznika in ga opogumila za vztrajanje $v$ danih okoliščinah. Še po toliko desetletjih njeni odtenki ožarijo grenke spomine. Ti spomini so razvrščeni kronološko, smiselno po logiki dogajanja od začetka druge svetovne vojne do njenega konca oz. od okupacije do osvoboditve.

Čeprav so Slovence preganjali z njihovih tal vsi trije okupatorji: italijanski, madžarski in nemški, se tukajšnja obravnava nanaša samo na nemško okupacijo, ker je v omenjenem zborniku le en ohranjen spomin na italijanski del okupiranega slovenskega ozemlja, pa še v tem primeru gre za eno od koncentracijskih taborišč, v katerih gre za popolno omejenost gibanja in ne za konfinacije, pri katerih gre za delno omejenost gibanja.Z njimi je nekako mogoče primerjati slovenske izgnance $v$ Srbijo v okupirani Jugoslaviji in v okupatorsko nacistično Nemčijo.

Gradivo za tukajšnji članek se opira izrecno na zbornik spominov iz omenjenih treh gorenjskih občin. Poudarek je na otroških spominih, ki so jih po dolgih letih zapisali že kot odrasli. Spomini na odtrganost od doma so bili dolga desetletja zaradi splošno odklonilnega razmerja do okupatorja samo grenki in bridki; še toliko bolj, če je bil prizadeti poln gneva zaradi kakršne koli izkušnje krivice. Šele po dolgih letih lastnih življenjskih izkušenj, v zrelih letih izza turobnega razpoloženja zasije kakšen droben žarek, ki je vsaj za hip olajšal trde razmere ali mučno situacijo in okrepil zaupanje v človeka ter mu pomagal fizično ali psihično preživeti. Spomini so nastali na pobudo območne organizacije Društvo izgnancev Slovenije 1941-1945 iz Škofje Loke in so zato nastajali nekako $v$ enakem časovnem obdobju.

Zaradi varčevanja s prostorom so spominski citati v drobnem tisku. Zaradi preglednosti in jasnosti, v kakšnem kontekstu se je zgodilo kaj, kar priča o lepem in dobrem $v$ človeku, so označeni krepko. V prvem oklepaju sta na prvem mestu navedena ime in priimek pisca, nato z zvezdico leto njegovega rojstva. Tako lahko bralec izračuna, koliko let je imel ob dogodku, ki se ga spominja.Za podpičjem sta v drugem oklepaju navedena samo letnica zbornika, ki je v uredništvu Rudija Zadnika izšel v Škofji Loki leta 1914, in strani, od koder je prevzeto besedilo.

\section{Negotovost}

Kljub temu da je bridko vsako nasilno slovo od doma, je še toliko hujše, če je popolnoma nepričakovano. Vsakršno, ubesedeno ali ne ubesedeno sočutje je blažilo neznosno bolečino:

Kmalu po okupaciji Jugoslavije sem teden dni počitnic preživela pri Krištanovih v Jarčji dolini. Imela sem se čudovito. Okopavali smo

\footnotetext{
${ }^{3}$ Asociacija na zelene in rjave uniforme nemške okupatorske vojske.
} 
krompir, igrala sem se $z$ domačim živalmi in se družila s prijateljico Jožo. V ponedeljek, 7. julija, pa sem vrnila domov v Žiri, ker sem imela slab občutek, saj se je v tistem času začelo izseljevanje Slovencev. Ata Krištan mi je rekel: „Pa kaj potem, če bodo odpeljali vaše. Ostala boš pri nas in boš naša (Breda Blaznik, "1928); (Zadnik 2014, 150).

Očeta je dober znanec obvestil, da je pri gestapu videl seznam družin za izselitev, na katerem je bila tudi naša. Mama nam je sešila nahrbtnike, v katerih smo imeli najnujnejše potrebščine. Živeli smo v stalnem strahu... (Marta Podobnik, *1932); (Zadnik 2014, 134).

Nenadoma me zgrabi huda bolest - je to konec naše domovine? [...] „Zakaj jokaš, mladenič? « Obrnem se, ob meni stoji Nemec. »Nismo mi krivi, da greste ...» »a, kdo pa vendar?« »Zahvali se sosedi!« Sočutno me gleda, nato pa skupaj greva $\vee$ hišo (Tone Mlakar, *1921); (Zadnik 2014, 54-55).

\section{II. Še na domačih tleh}

V Goričanah pri Medvodah, Šentvidu nad Ljubljano in v Rajhenburgu, današnji Brestanici ob slovensko-hrvaški meji, so bila zbirna taborišča, od koder so razporejali po kdove kakšnih merilih slovenske izgnance na sever ali jug. $\vee$ njih so mali potniki začeli dobivati trde življenjske izkušnje, ki jih je sem in tja osvetlila drobna pozornost. Največ je bila vredna, kadar je potolažila stalno lakoto.

- 22. julija 1942, točno po letu dni vstaje, je v zgodnjih jutranjih urah našo družino presenetila gestapovska horda s svojim vojaki. Iz spanja me je dvignil nemški vojak s čelado na glavi in me odnesel pred hišo, kjer so s culo že čakali ostali člani naše družine. Tega se zelo dobro spominjam (Alojz Filipič, ${ }^{* 1938) ; ~(Z a d n i k ~ 2014, ~ 216) . ~}$

- Goričane so mi ostale v spominu kot najslabši kraj od vseh, kjer sem moral kdaj koli živeti. [... ] Kljub vsemu hudemu sem imel tudi kakšen vesel trenutek, saj kot otrok nisem imel drugih skrbi kot tistih, ki so neposredno zadevale samo mene: uši, stenice, slaba hrana, ki je nisem bil navajen. Spoznal sem nove prijatelje. To sta bila Strojevcov Marjan (Kavčič) in Potokarjev Ludvik (Šmid) iz Podlonka. Oba sta bila šest do sedem let starejša in sta me verjetno imela za igračo. Okrog vratu sta mi privezala vrvico in me »fijakala« kot konja po hodnikih gradu. Takrat sklenjeno prijateljstvo se je nadaljevalo tudi v lagerju in se ohranilo tudi po povratku iz Nemčije (Peter Gortnar, $\left.{ }^{*} 1937\right)$; (Zadnik 2014, 353).

- Za vedno si bom zapomnila gospo, ki je zgodaj jeseni okrog svojega doma blizu zapora pobirala zgodnja jabolka. Ko sva s prijateljico hodili po dvorišču graščine - zapora - ter opazovali gospo in jabolka, ki jih je pobirala, nama je pomahala. Hitro sva stekli k njej in dala nama je jabolka. To se je ponovilo še drugi dan, a takrat je to verjetno videl nemški stražnik. Ko sva tretji dan prišli tja in čakali gospo, je ni bilo več, 
in tako so jabolka od takrat naprej ležala na tleh, da sva jih lahko samo gledali. Iz Goričan so nas odpeljali na železniško postajo v Medvode in nato naprej v neznano (Marija Twrdy, ${ }^{* 1936) ; ~(Z a d n i k ~ 2014, ~ 66) . ~}$

- Po nekaj dneh bivanja v Šentvidu smo se okrog polnoči podali na našo dolgo pot. Pri izhodu je sedela komisija, ki nas je popisala in vzela dokumente, ki so nam jih vrnili šele ob prihodu v Srbijo. [...] Vlak je imel postanek $v$ Šiški. Tam nas je pričakala množica ljudi in nas zasipala z vsem, kar so imeli doma (kruh, limone, kuverte itd.) (Helena Leben, *1929); (Zadnik 2014, 131).

- V gradu Rajhenburg so živeli menihi. Imeli so tudi živino in krave so se pasle okoli poslopja. Spominjam se dobrega meniha, ki je videl, da smo otroci lačni, in nas je naučil, da smo na paši molzli krave kar v usta. Ko je to opazil nemški paznik, je sledila kazen in nas niso več pustili na prostost (Robert Tratnjek, $\left.{ }^{*} 1937\right)$; (Zadnik 2014, 184).

- Največ sva bila skupaj z Miklavžem Žebretom. Izseljeni so bili njegovi starši, on pa je ostal v Loki pri teti. Nemški vojak je namreč rekel, naj dojenček ne gre na pot, ker ne bo preživel (Peter Pokorn, " 1939); (Zadnik 2014, 88).

- 12. septembra 1941 so nas Nemci s kamionom odpeljali v zbirni center na grad Rajhenburg $\vee$ Brestanico. Dobri nemški vojak je mami svetoval, naj s seboj vzame voziček, da bo imela kam položiti dojenčico. [...] Oče je znal zelo dobro govoriti nemško. Spoprijateljil se je s starejšim nemškim stražarjem, ki je bil enkrat na teden dežurni. Oče mu je verjetno potožil, da imamo šestmesečno punčko, ki je mama ne more nikjer umiti ne oprati in posušiti plenic, ter da se neprestano joka, ker je vsa njena koža v ranah, pa tudi za jesti nima. Mama jo je sicer še dojila, a ker je bila tudi ona lačna, je imela premalo mleka za dojenčico. In ta dobri stražar nam je pomagal takrat, ko je dežural. Poskrbel je, da smo me tri odšle iz lagerja $k$ starejšim Nemkam, ki so bivale v bližini, kjer je mami skopala sestrico in oprala plenice, jaz pa sem dobila košček kruha in mleka (Breda Pleško, ${ }^{* 1936) ; ~(Z a d n i k ~ 2014, ~ 47-48) . ~}$

\section{Izgnanstvo Slovencev na jug: v okupirano Srbijo}

Na podlagi Hitlerjevega ukaza: »Naredite mi to deželo zopet nemško!« (Repe 2015, 24: op. 2) je Hitlerjeva Nemčija zavzela Slovenijo kot svojo deželo, Srbijo pa samo okupirala; zato so Srbi obdržali jezik in tudi denar (Breda Blaznik, *1928) (Zadnik 2014, 169).

$\checkmark$ navedeni knjigi so po abecedi navedeni srbski kraji, kamor so bili odpravljeni in v njih vsaj nekaj časa bivali slovenski izgnanci: Aleksandrovac, Arandjelovac, Arilje, Batajnica, Brezovica, Čačak, Dupci, Gornja Seginja - Župa, Gornji Stupanj, Kopaonik, Kruševac, Osladič, Požarevac, Radobudja, Smederevska Palanka, Užička Požega, Valjevo, Velika Plana, 
Veliko Orašje, Zaječar, Sombor v Vojvodini (Zadnik 2014, 397). ${ }^{4}$ Njim je treba dodati še vsaj Šid v Sremu. ${ }^{5}$

Čas vojne je čas grozot, strahu, bolečin, hudobije in nerazumnih dejanj. Odraslemu človeku ga je težko sprejeti, preživljati in razumeti. Če pa si otrok, te to prizadene mnogo globlje in te na svojstven način zaznamuje za celo življenje, čeravno se niti ne zavedaš vseh nevarnosti in dejanj takega časa (Janez Tancek, ${ }^{* 1932)}$; (Zadnik 2014, 185). ${ }^{6}$

Kako o tem po sedemdesetih letih pričujejo slovenski izgnanci, ki so pristali v Srbiji? Snov je razvrščena kronološko in kolikor mogoče smiselno:

\section{Pot}

- V aprilu 1941 se je začelo. Spominjam se zavijanja siren ... V šolo nismo več hodili, očka so zaprli, Slovenijo so zasedli Nemci. [...] Spominjam se, kako so Nemci na velikem travniku na Jožefovem hribu, pri Deutschu se je reklo, zasliševali veliko Slovencev. Tudi mojo mamo. Hoteli so njeno priznanje, da izvira iz nemške družine. Niso ga dobili. Kmalu po tem dogodku so nas izgnali. [...] Spominjam se noči v veliki kleti, v kateri je bilo veliko ljudi, družin s prtljago, na kateri smo nekako prespali noč. Naslednji dan so nas po dolgi vožnji v živinskih vagonih izkrcali v Paračinu. Prijazni domačini so nas sprejeli medse in z nami jedli pri skupnem kotlu (Cvetka Maksin, ${ }^{* 1929) ; ~(Z a d n i k ~ 2014, ~ 198-199) . ~}$

- 4. julija 1941 je tudi našo družino skupaj z učitelji, duhovniki in drugimi doletela usoda izgnanstva. Po treh dneh bivanja v Škofovih zavodih v Šentvidu pri Ljubljani, kjer je bilo zbirno taborišče za nas, priključili pa so nam tudi izgnance iz Begunj, so nas 7. julija opolnoči naložili $\vee$ pulmane in nas popeljali na negotovo pot. [...] $\vee$ Zidanem Mostu smo si oddahnili, ker vlak ni zavil proti Nemčiji. Zjutraj so nam v Zagrebu članice Rdečega križa postregle s toplim čajem in prigrizkom, ki so ga bili najbolj potrebni mlajši otroci in starejši ljudje (Ivan Reven, *1925); (Zadnik 2014, 207).

- Pisalo se je leto 1941. Nemci so zasedli našo deželo in seveda smo tudi v Mariboru začutili nemški teror. Nekega dne v juniju so starši

\footnotetext{
${ }^{4} \mathrm{~V}$ sezname se je prikradlo nekaj očitnih napak. Karlovac je skoraj na meji Slovenije in Hrvaške, in ne v Srbiji, Auschwitz pa je danes na Poljskem in je bil tedaj zagotovo v od nemškega okupatorja zasedeni Nemčiji. Tudi poljsko ime je napisano napačno. Ne Osvitencim, temveč po poljsko Oświęcim. Res pa je, da je treba preveriti, katero je bilo uradno ime tega nesrečnega kraja pred drugo svetovno vojno - je spadalo pod Nemčijo (torej Auschwitz) ali Poljsko (Oświęcim).

${ }^{5}$ Prim.: Marija Demšar, Pisma iz Šida, Galerija slika »Sava Šumanović«, Šid 2014; Marija Stanonik, Etnologija u pismima i slikama, Etnografski institut, Srpska akademija nauka i umetnost (Biblioteka Životopis, knjiga 5), Beograd 2008.

${ }^{6}$ Pri navedkih je v prvem oklepaju zmeraj naveden/-a avtor/-ica zapisa in z zvezdico označena njena/njegova rojstna letnica. Letnica v drugem oklepaju se nanaša na zgoraj omenjeni zbornik in mesto objave $v$ njem.
} 
dobili ukaz, naj se čez dve uri zberemo v meljski vojašnici. Od tam so nas $\vee$ živinskih vagonih transportirali $\vee$ Srbijo in nas poselili po različnih krajih. Naša družina je pristala v Šabcu. Imeli smo srečo, saj je kmalu k nam pristopila starejša ženska in nam ponudila streho nad glavo (Peter Rozman, *1941); (Zadnik 2014, 109).

- Kmalu po okupaciji so Nemci odpeljali očeta v zapore v Begunjah, od tam pa $\vee$ zapore $\vee$ Šentvid pri Ljubljani. [...] Z drugim transportom izgnancev so nas 25. julija 1941 v živinskih vagonih odpeljali $\vee$ Srbijo. Naša pot se je končala v Smederevski Palanki, kjer nam je gostoljubje nudila družina Stanojevič. [...] Iz hvaležnosti do ljudi v Smederevski Palanki, ki so nam olajšali bivanje v Srbiji, je oče še dolgo vzdrževal stike z njimi in se tudi udeleževal sprejemov vlaka bratstva in enotnosti (Marjeta Zupančič, *1936); (Zadnik 2014, 213).

- Po slabem tednu bivanja v Šentvidu so nas 7. julija 1941 v živinskih vagonih odpeljali v Srbijo. [...] Po nekaj dneh smo prišli v Krnjevo pri Velikem Orašju. Na železniški postaji so čakali domačini, da nas odpeljejo na svoje domove. Vsakemu je bilo določeno, koga naj odpelje. Po nas je prišel nekdo z vpreženim volom (Jernej Gortnar, *1935); (Zadnik 2014, 244-245).

- Tretji dan ponoči smo bili z vlakom prepeljani v Valjevo v Srbijo. V Valjevu v vojašnici je ostalo veliko izgnancev. [...] Po prihodu iz Ljubljane $v$ Valjevo smo bili razpuščeni in Nemci kot okupatorji nad nami niso več izvajali terorja. Popolnoma smo bili odvisni od pomoči Srbov. Daleč od svoje domovine in doma z minimalno prtljago smo občutili veliko žalost. Nismo vedeli, koliko časa bomo doživljali to usodo in kaj vse nas še čaka. Moram povedati, da so nas Srbi zelo lepo sprejeli in nam pomagali (Mira Antonija Bernik, *1928); (Zadnik 2014, 126-127).

- Peljali smo se skozi Čačak in Kraljevo, v Kruševcu pa se je vlak ustavil. Ura je bila približno 11 zvečer. Izseljenci smo bili dodeljeni srbskim kmetom, ki so nas z vprego čakali na postaji ves dan. [...] Bili smo izmučeni in na vozu smo sedeli in spali kot vreče peska. Zraven smo imeli svoj "punkl«, večinoma z neuporabnim stvarmi. Šele ob $1 \mathrm{~h}$ popoldne smo se pripeljali $v$ vas Vitkovo. Tam se nas je usmilil učitelj ter mene, Jaroša in mami naložil na gik, lahek dvokolesnik, vprežen s konjem. V petnajstih minutah smo se pripeljali pred Kostićev dom. Tatek je z voli tja dospel šele čez kakšno uro. [...] Sprejeli so nas zelo lepo. Mlad gospodar Vule se je navezal na našega tatka in ga vodil povsod naokrog po svojem posestvu, med vinograde in na svojo ovčerejo $v$ planine (Breda Blaznik, $\left.{ }^{*} 1928\right)$; (Zadnik 2014, 153).

- Prispeli smo v Kruševac v Srbijo. Na postaji je bilo nekaj domačinov z vozovi, vpreženimi z voli. Naša družina se je povzpela na voz in odpeljali so nas v vas Tržac, ki je bila od Kruševca oddaljena približno 30 km. Tam so nas nastanili v staro zapuščeno šumadinsko kočo, narejeno iz lesa in ometano z blatom. To je bila koča z dvema prostoroma in vežo (Frančiška Finžgar, ${ }^{* 1928) ; ~(Z a d n i k ~ 2014, ~ 69) . ~}$ 
- Ob štirih zjutraj so nekaj vagonov pustili na železniški postaji v Smederevski Palanki, polovico pa so jih peljali naprej do Velike Plane, kjer so nas nemški spremljevalci predali krajevnim oblastem oz. nemški komandi mesta. [...] Po neskončnih barantanjih nas je prevzela sočutna ruska duša Lija Samohvalov, ki je tudi sam moral ob koncu prve svetovne vojne kot mladenič zbežati iz vojske. Mati mu je še prej $v$ jopič všila zlatnik za najbolj kritičen trenutek. Meščani so nam v kleti svoje gimnazije delili skromna kosila in večerje. Potem pa smo se dela zmožni morali sami kje zaposliti in preživljati (Ivan Reven, *1925); (Zadnik 2014, 208).

- Vlak nas je odpeljal preko Sarajeva. Ponoči smo se ustavili v Smederevski Palanki. Domačini so se prebudili in nemo opazovali nepoznano množico. Prišli smo do osnovne šole, v kateri je bil pripravljen vojaški kotel za kuhanje. Mame so se trudile kaj skuhati in v kotel dajale, kar so dobile od dobrih ljudi, očetje pa so pomagali lupiti krompir (Helena Leben, *1929); (Zadnik 2014, 131).

\section{Bivanje}

- Že ob samem prihodu v Čačak smo imeli smolo. Nismo in nismo našli strehe nad glavo. [...] Povsod je bilo postavljeno vprašanje: »Imate decu? « In odgovorila sta: »Imamo«. Odgovor je bil vedno enak: »Sa decom ne primamo«. Vsak dan smo se bali, da nam do začetka policijske ure ne bo uspelo najti prenočišča. Prvi večer nas je k sebi sprejel jugoslovanski vojak, ki je mojo mamo prepoznal z žirovske pošte. V Žireh je kot graničar služil vojsko. Ves naslednji dan sva z Jarošem čakala $\checkmark$ parku, mami in tatek pa sta hodila okrog in iskala stanovanje. Neka gospa je oddajala sobe, a ji gospodinja ni pustila sprejemati žensk. Prišepnila jima je, naj v primeru, da ničesar ne najdemo, pridemo k njej. Tistega dne je bila policijska ura že ob $18 \mathrm{~h}$ in ob 17.39 smo se res zatekli k njej. Vsi štirje smo prespali v eni zakonski postelji (Breda Blaznik, *1928); (Zadnik 2014, 156).

- Vsak dan opoldan smo jedli v menzi za izgnance, ki jo je finančno podprla mariborska občina. $V$ Čačku in okolici je bilo namreč veliko Mariborčanov in drugih Štajercev. [...] Po dveh mesecih zdoma smo se vrnili v Čačak. Ljudje v Donji Trepči so nas imeli radi. [...] Čika Ljubo nam je veliko pomagal. Preko njegovih sorodnikov smo dobili stanovanje v nizki nepodkleteni pritlični hiši s štirimi sobami. [...] Živeli smo kot Robinzoni. Steklenico smo imeli za valjar, zaboj za drva je služil kot stol itd. V tej hišici smo preživeli 4 leta (1941-1945). Hvala bogu za tega trgovca! (Breda Blaznik, *1928); (Zadnik 2014, 158 in 163-164).

- Dobri Slavko Marjanović nam je za vedno ostal hvaležen in ni pozabil jutra, ko so se Nemci vrnili s kazensko ekspedicijo ter brez talca odšli z njegovega dvorišča. Velikokrat je rekel: "Anica, pošalji mi decu, da se najedu!« Večkrat nas je povabil na obisk, za njihove praznike: sla- 
vo, božič in novo leto. Včasih je na tržnico pripeljal pridelke za prodajo, nato pa na voz naložil nas in nas peljal k sebi domov. Tja sva običajno šla sama z Jarošem in vrnila sva se peš (Breda Blaznik, *1928); (Zadnik 2014, 170).

- Spomladi 1944 je mamičin poštni kolega predlagal, naj kupimo prašiča. [...] To bi morali storiti že prej. Vendar, misliš si - nimam denarja, ne svinjaka ne pomij. Z ljudmi smo imeli res srečo. Ne vem, kaj bi brez tega Srba, ki je založil denar in nam pomagal pri vzreji (Breda Blaznik, ${ }^{* 1928) ; ~(Z a d n i k ~ 2014, ~ 171-172) . ~}$

- Bilo je težko začeti iz nič. Nismo imeli hrane, niti prave posode, da bi lahko kaj skuhali. A nekaj sosedov kmetov je bilo dobrih; prinesli so nam nekaj posode, ki je sami niso več rabili. Drugi so prinesli krompir in nekateri tudi kuhano hrano, ki jim je ostala. Spominjam se dobre sosede, ki je rekla, da če bodo imeli za jesti njeni otroci, bodo jedli tudi naši (Frančiška Finžgar, ${ }^{* 1928) ; ~(Z a d n i k ~ 2014, ~ 69) . ~}$

- Tako smo se hranili, dokler nismo dobili stanovanja pri eni od srbskih družin. Prišli so kmetje in izbrali ljudi za delo na kmetiji. [...] Domačini do nas večinoma niso bili slabi (Helena Leben, *1929); (Zadnik 2014, 131).

- Peljal nas je na svojo kmetijo, »bašto«. Tako so rekli ograjeni kmetiji, znotraj katere so stali hiša, kozolec, ${ }^{7}$ malo stran od njiju še svinjska kuhinja in lopa, in to je bilo naše bivališče za neznano dolgo. Soba je bila velika mogoče $6 \times 6 \mathrm{~m}$, z oknom in vrati, brez vode, brez ogrevanja in brez poda. Na tleh je bila stlačena ilovica. Ata je prosil za nekaj desk in malo orodja, in je v enem kotu približno pol metra nad tlemi naredil pograd ( $2 \times 3 \mathrm{~m})$, kjer smo spali otroci, Jelka, Mici, Janez in jaz. Dojenček Joža pa je spal v nekem zaboju s slamo. Neki domačin je prinesel zelo razmajano staro posteljo, $v$ kateri sta spala ata in mama. Prostor je bil brez ogrevanja in od nekod so prinesli pečko, majhen gašperček, ki je služil za ogrevanje sobe, kuhanje in segretje vode (Jernej Gortnar, *1935); (Zadnik 2014, 244-245).

- Naslednja postaja je bil Zaječar, kjer smo imeli spodobno domovanje. Sledil je Veliki Bečkerek, danes Zrenjanin, kjer smo dočakali konec vojne. Očka je dobil službo na sodišču v Velikem Bečkereku. Domačini so nam zelo pomagali pri urejanju našega skromnega doma (Cvetka Maksin, *1929); (Zadnik 2014, 198-199).

- Ti mladi fantje so kmalu začeli delati pri domačih kmetih v vasi Osladić in si s tem prislužili stanovanje in hrano. Na dvorišču šole je bila majhna baraka (drvarnica), kjer so ženske oziroma matere kuhale skromne obroke hrane. Domačini so poskrbeli za nas, poklanjali so nam hrano in material za kuho (Mira Antonija Bernik, "1928); (Zadnik 2014, 126).

\footnotetext{
${ }^{7}$ To je morala biti kakšna drugačna stavba, saj v Srbiji kozolcev pač ni. Morda je bila lopa, kolnica ali kaj podobnega.
} 
- Med nami, izgnanci, je bil tudi vojaški zdravnik iz Škofje Loke, dr. Čavić, ki je skrbel za zdravljenje domačinov iz Osladića in okolice. Vse, kar so mu v zameno za zdravljenje podarili domačini, je delil z nami (Mira Antonija Bernik, ${ }^{*}$ 1928); (Zadnik 2014, 126).

- Arilje je bilo majhno mesto. Na pobočju je stala cerkvica sv. Ahilija. Vsa okolica je bila podeželska. Učiteljica Andjela nas je včasih fotografirala in v družinskem albumu imamo slike, na katerih smo med samimi kamilicami. Ker je znala šivati, je zame in za Štefana naredila luštni srajčki s pikčastimi vzorci. Sestrici Marici pa je sešila oblekico, ki jo nosi na sliki (Peter Pokorn, ${ }^{* 1939) ; ~(Z a d n i k ~ 2014, ~ 87) . ~}$

- Ker je vojna še trajala, so po mestu hodili tudi vojaki. Ne spominjam se, da bi bili nasilni. Naj dvorišču ob hiši, kjer smo stanovali, so bili nekaj časa bolgarski vojaki ${ }^{8}$ in spominjam se, da so otrokom dajali čaj, ki je bil za nas zelo sladek, ker si takega sami nismo mogli privoščiti (Peter Pokorn, ${ }^{*}$ 1939); (Zadnik 2014, 87).

- V Srbiji mi kot otroku ni bilo tako grozno. Hrano smo imeli, lačni nismo bili. V Ribnici je bilo težje. Staršem je moralo biti še bolj grozno. Morali so preživljati veliko družino in otroku, ki prosi za kruh, je zelo težko reči, da ga ni. Ni bilo lahko, posebno ne za starše (Jernej Gortnar, *1935); (Zadnik 2014, 247).

\section{Izgnanstvo Slovencev na sever: v nacistično Nemčijo}

Nacistična vojna oblast je $v$ Tretjem rajhu ustanovila taborišča treh vrst: uničevalna, kaznilniška, delovna. Zaradi morebitne primerjave za tukajšnjo obravnavo pridejo $v$ poštev le tretja, in še to pogojno, kar se lepo vidi iz izjav v navedenih odlomkih. Vtis je, da so bili v Nemčijo izgnani Slovenci nastanjeni veliko bolj strnjeno in pod nadzorom kot $v$ Srbiji. Res so jih izkoriščali kot ceneno delovno silo, toda kljub temu jim je bilo veliko lažje kot v kaznilniških in uničevalnih taboriščih.

Nekateri nemški državljani so, morda pod vtisom propagande, razumeli prihod tujih ljudi v njihovo okolje kot dobro delo, medtem ko so drugi brez priziva pred očmi imeli okupatorsko logiko:

- Mama je govorila z enim od poveljnikov, rekli smo jim lagerfirerji, in ga vprašala, kaj bo z nami. Odgovoril ji je, da tega ne ve, zagotovo lahko pove le, da ne bomo šli nikoli več domov (Janez Dolinar, *1928); (Zadnik 2014, 105).

- Ker sem se že pred izgnanstvom učil za ključavničarja, sem iz lagerja hodil delat k domačinu - privatniku električarju. Veliko me je naučil in ne morem se preveč pritoževati, da mi je bilo hudo. Ko sva se pogovarjala, mi je rekel, da smo pri njih bolj varni, zato so nas prepeljali k njim (Avgust Bertoncelj, ${ }^{*}$ 1925); (Zadnik 2014, 44).

\footnotetext{
${ }^{8}$ Treba je spomniti, da so bolgarski vojaki pripadali velikonemški opciji.
} 
- Težki so bili trenutki, ko nas je okupator odgnal od doma. S tem se ne moremo sprijazniti. Pa vendar so mi ostali tudi spomini na ljudi tam daleč, od katerih smo bili deležni tudi prijazne besede (Marta Podobnik, ${ }^{*}$ 1932); (Zadnik 2014, 136).

- Prejšnjega, dobrega starejšega Nemca je zamenjal esesovec, po rodu Poljak (Jože Drnovšek, " 1927); (Zadnik 2014, 64).

Predolg je seznam nemških krajev, v katerih so se slovenski izgnanci morali nastaniti, le seštejemo jih lahko: Bavarska (58), Spodnja Šlezija (49), Saška (78), Brandenburško (7), Hannoversko (8), Türinško (20), Würtemberško (14), Badensko (13), Švabsko (11), Frankovsko (5). ${ }^{9}$ Vsega skupaj jih je okrog $260 .^{10}$

Nekatere družine in posamezniki so naleteli na zelo hude razmere in okoliščine, drugi pa so imeli srečo. Najbrž je bilo doživljanje novega okolja odvisno tudi od razmer doma, od koder so bili pregnani, in od sposobnosti sprejemanja v dano situacijo. Karol Dolenc (Zadnik 2014, 256-257 in 259) je v pismu februarja 1943 stvaren: »Obravnavajo nas kot delovne ljudi.« Zadovoljen je z bivališčem: »Ni tak slabo, kot smo pričakovali. [...] /T/udi sicer je vodstvo lagerja napravilo na nas zelo dober vtis in posebno vodja lagerja je zelo simpatičen človek."

Karakteristične povedi si zapovrstjo sledijo kronološko in glede na starost otrok, od najmlajših v plenicah do najstnikov, ki jih je okupacijska oblast dala na razpolago domačinom (kmetom idr.), nekoliko starejše pa uporabila za tovarniško delo.

\section{Pot}

- Spomnim se, da me je nemški vojak vzel v naročje in mi ponujal hrano, pa nisem mogla jesti (Marija Kožuh, *1934); (Zadnik 2014, 107).

- Moj oče Jurij in mati Angela sta sodelovala pri Osvobodilni fronti. To je bil verjetno glavni vzrok, da so nas izselili. [...] Nemci so prišli ob štirih zjutraj. [...] Iz Goričan smo odšli v taborišče Burghausen. Tam bi skoraj umrl, saj sem med potjo zbolel za davico. Neki nemški bolničar mi je kar s trsko potlačil tableto v grlo. Pustili so me, saj zdravil ni bilo, in mati je že mislila, da je po meni (Jakob Rihtaršič, $\left.{ }^{*} 1941\right)$; (Zadnik 2014, 222).

- Na železniški postaji me je lagerfirer Hans, ki je bil v zeleni vojaški uniformi, dvignil iz živinskega vagona, me nekaj časa gledal v oči in potem postavil na tla. Takrat sem bil star tri leta (Janez Kuselj, ${ }^{* 1940) ; ~}$ (Zadnik 2014, 201).

\footnotetext{
${ }^{9} \mathrm{Z}$ upoštevanjem, da niso natančno prešteti.

${ }^{10}$ Kraji izgona Slovencev med 2. svetovno vojno so povzeti po zborniku Naši spomini, Zbornik izgnancev, beguncev in pregnancev iz občin Gorenja vas - Poljane, Škofja Loka, Železniki in Žiri. Društvo izgnancev Slovenije 1941-1945, Območna organizacija Škofja Loka, 2014.
} 
Iz le treh znamenj dobrote se vidi, da so bile razmere na poti $v$ daljno Nemčijo veliko bolj trde in spremljevalci - nemški vojaki nedostopni za stiske malih izgnancev. Prva zadržanost do neznanih prišlekov v okoljih, kamor so jih nastanili, je razumljiva, toda sčasoma se je nezaupanje do njih uneslo:

Domačini so bili do izseljencev večinoma strpni in tolerantni. Pripovedovali so, da je bilo pred našim prihodom rečeno, da pridejo $v$ lager banditi.Zato so bili večinoma pozitivno presenečeni, saj so si pod pojmom »banditi« predstavljali vse kaj drugega kot na pogled običajne družine, člani kakršnih so bili tudi sami. Tako med izseljenci kot med domačini so manjkali mladi moški. Francka je $v$ dnevnik napisala: »drugega ne vidiš kot kakega starega pošvedranca ali babo!« (Peter Gortnar, ${ }^{* 1938) ; ~(Z a d n i k ~ 2014, ~ 378) . ~}$

\section{Bivanje}

- Domov smo se vrnili meseca maja 1945. Doma je bilo vse izropano. Vse je bilo prazno. V lagerju smo imeli to srečo, da smo bili lahko starši in otroci skupaj (Janko Bertoncelj, ${ }^{* 1935) ; ~(Z a d n i k ~ 2014, ~ 230) . ~}$

- Življenje v lagerju je bilo mučno za starejše, otroci pa smo se tega manj zavedali. Ker nismo bili razvajeni, smo nekako prestajali to tragedijo (Alojz Filipič, ${ }^{* 1938) ; ~(Z a d n i k ~ 2014, ~ 216) . ~}$

- Tudi »življenjski standard« ni padel preko noči in starši so se trudili, da je zame vedno ostal kakšen priboljšek, tudi če za druge ni bilo. Ne spominjam se, da bi bil kdaj koli posebej lačen. Obroki, kakršni so že bili, so bili redno trikrat na dan (Peter Gortnar, " 1938$)$; (Zadnik 2014, 365).

\section{a) Otroci}

- Prispeli smo v lager Hegne pri mestu Konstanz pri Bodenskem jezeru. Mama mi je pripovedovala, kako dober je bil tam lagerfirer, posebno rad je imel otroke. Bil je poročen, a otrok ni imel. Ko smo od tam odšli, je moji sestri, ki je bila starejša od mene, za rojstni dan podaril manjšo stensko uro na uteži, ki jo hrani še danes (Vera Šiberle, *1939); (Zadnik 2014, 60).

- Zaradi brata Franca, ki je šel v partizane, in zaradi lege našega doma, ki je bil blizu gozda in na razpotju med Poljansko dolino in Primorsko, smo bili označeni kot zavezniki partizanov. Zato nam je bila odrejena selitev. [...] Naša dokončna postaja je bila Nemčija - Feilnbach. Sledil je razpored vseh izgnancev na delovna mesta po tovarnah, kmetijah, gostilnah in drugod. Mene so si podajali iz rok v roke. Kdor je bil prost, je pazil name. Največ se je z mano trudil brat Tone. Ata je v jedilnici hodil od enega do drugega in prosil, če ima kdo kakšen dober krompir za slabotno Minkico. Dobivali smo namreč ves črn krompir, skratka neužiten. Sestra Rezka je jokala, ko me je previjala, saj je bila moja koža velikokrat opečena do krvi. Po sili razmer sem bila večkrat 
sama, neoskrbovana, zaklenjena v sobo (Minka Markelj, *1940); (Zadnik 2014, 274).

- Za moje varstvo so pristopili na pomoč tudi ostali izgnanci. Spominjam se Zapotoških in Bohinčevih iz Martinj Vrha. Še vedno imam v spominu mladega lepega fanta z zelo urejeno frizuro - Štefana Pirca iz Moravč. Veliko je vasoval pri naši družini, kot mnogi drugi izgnanci. Zmeraj me je posedel na kolena in mi pel. Bil je odličen pevec in požirala sem njegovo petje. Bil je prvi, ki mi je predstavil lepoto glasbe, kateri se še danes razdajam (Minka Markelj, "1940); (Zadnik 2014, 279).

- Blizu lagerja je stala bogato obložena češnja. Seveda je bila nam, izgnancem, strogo prepovedan sad. Za nas, otroke, pa tudi previsoka in nedosegljiva. Ko jo je lastnik prišel obirat, smo otroci takoj naredili špalir okrog drevesa. Z iztegnjenimi ročicami in poželjivimi pogledi smo prosili: »Kirše, kirše. "Danes vem, da bi njegova košara ostala prazna, če bi nam izpolnil želje. Toda njegove dlani niso namenile nič darov narave. Noben slikar ne bi mogel narisati naših poželjivih gorečih pogledov in noben pisatelj jih ne bi mogel opisati.

Končno se je s polno košaro spustil na tla, med nas otroke. Se je moje drobno telesce in bledi obrazek s svetlečimi očmi dotaknil srca tega kmeta? Stopil je k meni, vzel iz košare dva para češenj in mi jih zataknil za ušesa, kot »ringelčke«. Neizmerna radost me je prevzela in z vso močjo sem stekla proti lagerju in kričala: »Ata, ata ... Kirše, kirše!« Stekla sem po stopnicah proti stanovanju. Tu pa sem srečala fanta, ki je prav tako hitel po stopnicah navzdol in mi spotoma snel en par češenj. Moje veselje se je spreobrnilo v jok. Ata mi je pritekel naproti in me tolažil, da se je kmet samo mene spomnil in da imam še dve češnji, en »ringelček« (Minka Markelj, *1940); (Zadnik 2014, 278-279).

- V Kindergartnu je z otroki delalo dekle Mariane. Od vseh učiteljic nas je edino ona kaj naučila. Spoznavali smo črke in se učili preprostih računov. Z nami se je igrala in lovila ter nas vodila na sprehode $\mathbf{v}$ bližnjo okolico. Posebno radi smo hodili na kraj, slabo uro oddaljen od lagerja. Reklo se mu je Die schönne Aussicht (Peter Gortnar, *1937); (Zadnik 2014, 355-356).

- Iz lagerja v Eckbergu so nas spet selili nazaj v Feilnbach. V vrtcu smo bili razdeljeni po starostnih skupinah. [...] Vzgojiteljica Marjana je bila z nami zelo dobra. Včasih smo se igrale z lesenimi igračami, ki so ostale še od prejšnjih izseljencev, dal nam je tudi nekakšne bloke, v katere smo pisali. Večkrat nas je odpeljala v naravo pod bližnji hrib in kar dolgo smo hodili, da smo se povzpeli na planino, kjer je bila vzgojiteljica doma. Esesovci so ugotovili, kako jo imamo radi in da z nami dela lepo, in nekega jutra je ni bilo več. Prišla je druga, ki pa ni bila

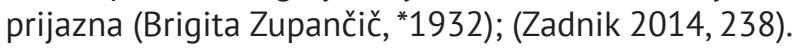

- Nastanjeni smo bili v nekem poslopju, kjer so bile prej nune, a so morale oditi. Hrana je bila zelo slaba, pa tudi malo je je bilo. Spomnim se, da me je neka ženska poklicala k sosednji mizi in mi dala en 
cel kuhan krompir. Paznik, ki je bil v rjavi SS-uniformi, je to videl, mi vzel krompir in me »nagradil« s palico po zadnji plati. [...] Drugi dan je bil apel. Ženske, ki mi je dala krompir, nismo več videli (Janez Kuselj, *1940); (Zadnik 2014, 201).

- Mestna vrata so bila ogromna, tako visoka, da smo hodili stat na "pante« (tečaje). Neka deklica ga je iztaknila, in mene je zagrabilo za glavo ter mi jo stisnilo. Neki pater (menih) me je rešil, čeprav smo jim radi nagajali. Zelo radi smo jih s fračo streljali v zadnjo plat (Jakob Rihtaršič, *1941); (Zadnik 2014, 222).

- V lepem spominu pa imam ata Bernarda, "starosto« iz Moravč, s katerim sva se $\mathbf{v}$ jutranjih urah sprehajala ob ribniku. Nekoč sem zaradi tega celo zamudil $v$ vrtec in me je vzgojiteljica kaznovala z udarcem šibe po vsakem prstu. Ko sem to povedal Bernardu, je bil zelo jezen. Počakal jo je pri vratih vrtca. Bila je bolj majhne postave, nosila je čevlje z visokimi petami, lase pa je imela spete $v$ visok čop, zato smo jo klicali Čopka. Zgrabil jo je za čop in ji zagrozil, da če se bo še enkrat znesla nad njegovim fantičem, ne bo imela več kaj zavezati na glavi. Tudi ona je zgubila mesto vzgojiteljice in na njeno mesto je prišla prijazna učiteljica Pavla Kump iz Stražišča pri Kranju. Atu Bernardu sem bil zelo hvaležen, ker se je potegnil zame (Alojz Filipič, $\left.{ }^{*} 1938\right)$; (Zadnik 2014, 216).

- Še en prijeten spomin imam, ki je vezan na Nikolaja iz soseske Racberga. Živel je v kajži, majhni hiški, vendar se je tudi zame v tistih razmerah dobil kakšen priboljšek. Ko so imeli koline, sem moral biti prisoten, vendar sem moral priti skozi zadnja vrata. Njegova mama je bila vedno v strahu, verjetno zaradi takratnih razmer. Sicer je bil Nikolaj nekoliko duševno prizadet, samo to naju ni motilo, zelo rada sva bila skupaj. Mamo so imeli zelo radi, ampak je odločno zavrnila ponudbo, da bi ostala v Nemčiji (Alojz Filipič, *1938); (Zadnik 2014, 218).

- Mama je delala kot služkinja. Ker je bila v najboljših letih in sposobna, je v lagerju Kirnhalden delala pri lagerfirerju, saj se je hitro naučila nemško. On je bil zelo strog, njegova žena pa bolj dostopna. Imela sta več otrok. V spominu mi je ostal Klaus, ki je bil moje starosti. Kadar lagerfirerja ni bilo doma, sem lahko tja prišel z mamo, da sva se s Klausom skupaj igrala, z bratom Jožetom pa sva dobila tudi kakšen priboljšek (Stanislav Ferle, ${ }^{* 1938) ; ~(Z a d n i k ~ 2014, ~ 142) . ~}$

Odrasli izgnanci so morali prijeti za odkazano delo, njihovi malčki pa so bili prepuščeni sami sebi in se niso niti zavedali, za kaj so prikrajšani, vendar so še ohranili otroško navihanost.

Opaža se razlika v odnosu do deklic na eni in dečkov na drugi strani. Najbrž so posebej trpki spomini na kaznovano dobroto. Največji uspeh zanje je bil, kadar so jih sprejeli medse otroci domačinov.

b) Najstniki

Ti so se že bolj zavedali kritičnega položaja in si iz njega skušali eksistencialno tudi sami pomagati. Sem in tja so naleteli tudi na politične 
izjave, sami pa se v tem pogledu najbrž niso izpostavljali. Delali so pri kmetih in obrtnikih, trgovcih in drugih uglednih družinah:

- Pa se je Bratu Boltetu nasmehnila sreča. Dodeljen je bil za pomoč na kmetijo, imenovano »Mostmile«. Tam pa niso bili nastrojeni proti izgnancem, ampak proti Hitlerju. »Kaj nam je bilo treba te vojne? Kaj nam mar Jugoslavija, saj imamo svojega dovolj. Hitler, ta vojna nam je vzela sinove, brate, može, so se jezili na vso moč. [...] Na njej je bil Bolte priljubljen, nikoli lačen in nikoli zaničevan (Minka Markelj, ${ }^{* 1940) ; ~}$ (Zadnik 2014, 275).

- Iz Mettenheima so nas preselili v Weichs, kjer sem delal pri kmetu. Tam sem se najbolje počutil, saj mi je gospodinja včasih dala kakšen priboljšek (Janez Dolinar, *1928); (Zadnik 2014, 105).

- Po nekaj dnevih v Goričanah so nas v živinskih vagonih odpeljali proti Nemčiji. Pripeljali so nas v kraj Einstted. [...] Najprej sem delala na kmetiji. Gospodar je bil mizar, gospodinjina sestra pa je bila poročena z esesovcem, ki je večkrat hodil domov. Ne spominjam se, da bi mi povzročal kakšne težave (Marija Arhar, *1926); (Zadnik 2014, 139).

- Naša družina izhaja iz Dražgoš. Bila je kar številna, saj je bilo poleg mene še sedem bratov. [...] Vso noč smo se $v$ živinskih vagonih vozili v Nemčijo. V kraju Kulmbach so nas nastanili v stavbo, ki je bila nekakšna bolnišnica. Čez kakšen teden pa so nas odbirali za razna dela. Jaz sem šla na kmete in tam delala čez teden, $v$ soboto pa sem se vračala $v$ lager. Gospodinja me je imela rada in me je pregovarjala, da bi ostala kar pri njih, češ da imam doma še sedem bratov. Toda jaz ne bi pustila mame (Antonija Tolar, *1922); (Zadnik 2014, 235).

- Brat Jože je delal razna dela v tovarni, brat Franci pa je pomagal vrtnarju v lagerju. Vrtnar je bil že zelo star in mu je za njegovo delo dal tudi kakšen priboljšek (Alojz Pintar, 1935); (Zadnik 2014, 118).

- Tudi nas so v pozni jeseni 1944 preselili v Zwiesel. Spet sem hodil $v$ tovarno in včasih mi je uspelo pobegniti. Šel sem po neznanih okoliških vaseh in prosil za hrano. Tu in tam so se suhljatega dečka usmilili s koščkom kruha, mu dali v culo kak jajček ali pest krompirja. Dobrote smo s sestrama pospravili z največjim tekom (Roman Teržan, ${ }^{* 1930) ; ~}$ (Zadnik 2014, 116).

- 3. decembra 1941 smo prispeli v mesto Schwäbisch Hall. Iz mesta smo šli peš v lager in prispeli tja ob 11. uri zvečer. Nastanili so nas po sobah. Takrat sem bila stara 15 let - bila sem zdravo kmečko dekle. [...] Po enem mesecu je $v$ lager prišla ženska $z$ imenom Kastrogg in tolmaču ukazala, naj se vsa dekleta postavijo v vrsto. Sprehodila se je mimo nas in izbirala dekleta, ki so nato odšla k uglednim in bogatim družinam za služkinje. Mene je izbrala gospa Lina. [...] Pri njih sem delala sedem mesecev. Takrat sem dobila tudi delavsko knjižico (Arbeitsbuch), v kateri piše, kje in koliko časa sem delala (Viktorija Bernik, "1926); (Zadnik 2014, 82). 
- Kmalu sem tudi jaz šla v eno uro oddaljeni del novega mesta k družini za deklo. Gospa me je učila tudi kuhanja. [...] Po dobrem tednu sem zbolela za grižo. Slišala sem gospo, ko je po telefonu poklicala moža, naj pride pome in me odpelje k zdravniku. Toliko sem znala nemško, da sem razumela, kaj je govorila z možem. Nisem hotela k zdravniku. Odšla sem v lager in bolniška sestra Rdečega križa je dovolila, da ostanem tam. Ko sem si malo opomogla, sem morala spet na delo. Odšla sem k drugi družini s petimi otroki. Gospe sem se verjetno smilila, ker sem morala do njih veliko pešačiti, in mi je ponudila, da bi spala kar pri njih. Bila pa sem tako navezana na mamo in svoje, da sem odklonila (Olga Jenko, *1930); (Zadnik 2014, 80).

- Ko sva s sestro zvedeli, da je oče v delovnem taborišču Coburg na Bavarskem, naju je k njemu peljal sam lagerfirer. Seveda v začetku ni bil tako dober. Med potjo nama je priznal, da nas - zavedne Slovence - spoštuje, ker se kljub rosnim letom nismo pustili pregovoriti $v$ to, $k$ čemur so nas nagovarjali (Sonja Kavčič, " 1927$)$; (Zadnik 2014, 121).

- Bilo je točno eno leto po tistem, ko so nas selili - spet je bil moj god. Sestra Minka nas je na vsak način hotela videti in je prišla na obisk. Takrat sem delala $v$ mestni pralnici in gospa mi je dala dva tedna dopusta, ker me je obiskala sestra (Pavla Tolar, *1926); (Zadnik 2014, 268).

- Po nekaj mesecih so nas preselili v Niederfels, kjer pa smo ostali samo mesec dni. Od tam smo se spet selili v Burghausen. Tam smo ostali do 4. maja leta 1945. Mama je varovala male otroke, sestra Mici je bila snažilka na policijski postaji, sestra Justina pa je bila služkinja pri družini brez otrok. Oba sta bila trgovca in z njo nista ravnala slabo (Alojz Pintar, "1935); (Zadnik 2014, 117).

- Aretiral me je sošolec - belogardist. Ko sem ga vprašala, zakaj je to storil, mi je zaničljivo dejal: »Komanda je komanda!« Odpeljali so me $v$ šentjakobsko šolo, nato pa so me $v$ živinskih vagonih z drugimi odpeljali v taborišče Dachau. Tam je bila tovarna. Nekaj časa sem delala v kuhinji, nato pa sem morala iti delat za stroj. Mojster je bil dober z nami, a so ga kmalu poslali v vojsko. Nadomestil ga je drugi, ki pa z nami ni lepo ravnal (Marija Brišar, ${ }^{* 1926) ; ~(Z a d n i k ~ 2014, ~ 191) . ~}$

- Nekateri izseljenci so pri svojih delodajalcih dobili celo dopust. Izjemoma se je dalo odpotovati tudi na »obisk« v domovino. Kako se je do takega dovoljenja prišlo, mi ni poznano. Kot zanimivost lahko navedem dejstvo, da so dekleta, ki so delala v Klepper Werke, dobila dopust, vendar jih je lagerfirer po dveh dneh nagnal nazaj na delo (Peter Gortnar, ${ }^{*}$ 1938); (Zadnik 2014, 380).

- Gospod Meier je hodil v službo, ker je bil med vojno rezervni oficir protiletalske obrambe. Lastnika, gospod in gospa, sta bila do mene zelo dobra. Imela sta hčerko, ki je bila mlajša od mene. [...] Pri družini smo vsako soboto pekli 'melšpajz' (pecivo) in gospod ga je vsakokrat razdelil na štiri dele. Svoj del sem nato ob nedeljah delila s prijate- 
ljema Zdravkom in Miklom, ko sta me obiskala. Spoznali smo se že v transportu, ko so nas peljali v Nemčijo. [...] Ker se je približeval konec vojne, mi je gospod Meier uredil vse dokumente, da sem lahko še pred koncem vojne varno odšla domov (Terezija Wastl, " 1923); (Zadnik 2014, 77).

Najstniške dečke in deklice so že uporabili za resno delo. Pri delu na kmetih so se nekateri tako izkazali, da so jim nadrejeni (gospodinje, gospodarji) celo prigovarjali, naj ostanejo pri njih. Dekleta so prišla $\checkmark$ ugledne družine in se naučile kuhanja, gosposkih manir in skrbele za njihovo zdravje. Dečki so pridobivali spretnosti pri obrtnikih. Da jih jemljejo resno, so jim nadrejeni (npr. mojstri) v podjetjih dali vedeti tudi s formalnimi ugodnostmi (dopusti, delavske knjižice). Vendar so se stališča civilnih uprav in v taboriščih med seboj marsikdaj križala in v njih zaposleni niso mogli izkoristiti danih ugodnosti.

$\checkmark$ tem razdelku se zelo nazorno vidi, da »gre ljubezen skozi želodec«. Spomini na dobroto na tujih tleh so največkrat povezani s hrano.

Takole zveni nekaj žarkov dobrote celo iz koncentracijskih taborišč:

- Poleti 1943 sem prišel v komando »Zuschneiderei«. [...] Tovarno je vodil civilni mojster Wagner, še kar prijazen in ne preveč surov človek. Bil je izredno delaven in dober organizator (Tone Gortnar, ${ }^{* 1922) ; ~}$ (Zadnik 2014, 330-331).

- Iz te komande sem prišel v komando »Reinigung Sturmbann«. Bilo nas je samo šest, morali pa smo čistiti stražarske barake tik ob taborišču. V sobe stražarjev nismo smeli, čistili smo samo hodnike, stranišča in umivalnice. Delo samo na sebi ni bilo težko, bilo pa je precej neprijetno, posebno $\mathrm{v}$ mrazu, ker smo imeli roke ves dan mokre, pogreti pa jih nismo mogli nikjer. Tam smo včasih dobili skorje, ki so jih esesovci kar se da tanko rezali od svojega kruha. Med esesovci so bili tudi nekateri, ki so te skorje zbirali, jih hranili in nam jih skrivaj dajali. Škoda le, da smo tako redko prišli do njih (Tone Gortnar, ${ }^{* 1922) ; ~(Z a d n i k ~}$ 2014, 330-331).

- Pazniki so nas opazovali, da ne bi katera kaj pojedla ali skrila v žep. Spominjam pa se tudi dobrega, malo starejšega nemškega paznika, ki nam je dovolil, da smo na hitro vzele sadež, a tako, da tega drugi niso videli. Dovolil je tudi, da smo kdaj dobile kak krompir, ki ga je skrivaj prinesla kuharica Logarca, ki je bila kaznjenka v zaporu (Metka Hartman, *1925); (Zadnik 2014, 96).

c) Paketi

- Koncentracijsko taborišče Dachau: ko sem bil že na 14. bloku, se je zgodil še en čudež. Poklicali so me na taboriščno pošto (Postzensurstelle). Tam je esesovec pred menoj odprl paket velikosti škatle za čevlje. V njem so bile suhe hruške in prepečenec. Poslal mi ga je brat Viktor, ki je bil takrat na obveznem delu (Pflichtjahr) na Koroškem. Esesovec mi je zabičal, da moram domačim takoj sporočiti, da je pošiljanje paketov prepovedano, da pa bo naredil izjemo in mi paket izročil. Paket 
je na bloku povzročil pravo senzacijo. Dachau - pa paket, pa suhe hruške! (Tone Gortnar, *1922); (Zadnik 2014, 329).

- Tudi naša mama Lojzka iz Loke nam je proti koncu vojne (1944), prej ni bilo dovoljeno, enkrat na mesec poslala četrt kilograma težak paketek, v njem pa kakšne nogavičke ali sladkor. Vsakega paketka smo bili silno veseli, čeprav je bila $\mathbf{v}$ njih samo malenkost (Breda Blaznik, *1928); (Zadnik 2014, 169).

- Pošta in paketi so se lahko dobivali samo na lagerski naslov. Delodajalci so kakšnemu izseljencu včasih posodili svoj naslov. Če je lagerfirer to izvedel, so sledile sankcije, od denarne kazni (2 RM za pismo) do zaplembe in uničenja tudi na lagerski naslov prispele pošte, pa tudi »Lagerspere«. To je pomenilo, da je bil izhod iz lagerja dovoljen samo tistim, ki so šli na delo. Trajal je lahko tudi več dni (Peter Gortnar, *1938); (Zadnik 2014, 379).

Paketi so bili seveda dobrodošli za želodec, še bolj pa za moralo, da domači na izgnance niso pozabili. Saj jih niso smeli dobivati in če jim je bil kdo od Nemcev pripravljen $v$ tem pogledu iti na roke, ga je doletela kazen.

c) Zavezniki

- Gospod je vsak dan s kolesom hodil v službo, jaz pa sem morala za sorodnike hoditi $v$ gozd - žagala sem drva in to največkrat sama. Nekega dne se je pred mano znašel angleški padalec. Bil je lačen in dala sem mu svojo malico, on pa meni čokolado (Terezija Wastl, ${ }^{*} 1923$ ); (Zadnik 2014, 77).

- Aprila leta 1945 so taborišče osvobodili ameriški vojaki. Večina jih je bila črncev. [...] Še danes se spominjam temnopoltega Američana - vojaka - kako mi je v roke stisnil košček čokolade, se mi lepo nasmehnil in me dvignil na vagon. Po štirih letih je bilo to prvič, da je nekdo z mano delal tako lepo in da nisem bil deležen udarcev (Alojz Tomažič, $\left.{ }^{*} 1939\right)$; (Zadnik 2014, 100).

- Tudi vsega hudega je nekoč konec in prišel je dan naše osvoboditve. Po vasi so začeli patruljirati zavezniški vojaki, ki so bili z nami, izseljenskimi otroki, zelo prijazni. Ponujali so nam zavitke čokolade ali nam izročili kak predmet, da bi nas razveselili. Še danes hranim takrat podarjeni kovinski hranilnik, ki mi ga je dal ameriški vojak (Cilka Jelovčan, ${ }^{* 1934) ; ~(Z a d n i k ~ 2014, ~ 130) . ~}$

\section{Vračanje}

a) Še na tujih tleh

- Od srede aprila 1945 dalje se je lager pričel legalno in »organizirano« prazniti. Mislim, da so bila določena nekakšna pravila o vrstnem redu odpuščanja in odhajanja izseljencev proti domu. V lagerski pisarni, kjer je delala tudi Francka, je vsak kandidat za odhod domov dobil »Entlassugsschein«, neko odpustnico, ki naj bi dokazovala, da potuje 
legalno. Ko si dovoljenje dobil, si lahko odšel in potoval po načelu: »snadji se«. [...] Ata in Cesarjev Pepe sta se dogovorila, da se bomo ne glede na razmere držali skupaj. To je pomenilo, da bomo v vseh razmerah spoštovali pravilo: vsi ali nobeden! $\vee$ resnici smo se potem razšli šele v Kranju (Peter Gortnar, *1938); (Zadnik 2014, 366-367).

- 28. aprila 1945 nam je poveljstvo taborišča sporočilo, naj se pri njih prijavi, kdor želi odpotovati domov. Prijavilo se nas je 130 taboriščnikov. Odpotovali smo že naslednji dan, 29. aprila 1945. Vodstvo potovanja je prevzel Ludvik Bergant s Svetega Lenarta, ki je dobro obvladal nemški jezik. $V$ času pregnanstva je bil naš tolmač in prevajalec pisem, ki smo jih domov morali pošiljati v nemščini (Ciril Benedičič, *1928); (Zadnik 2014, 228).

- Zadnja postaja pa je bilo taborišče Neu Ötting, kjer sem pomagal v tovarni Kolenan Binder Fabrik; mešali smo material za lažji vžig premoga. Ko smo izvedeli, da bomo šli naslednji dan domov, mi je lastnik tovarne dal obleko za na pot, saj nisem imel skoraj nič za obleči (Janez

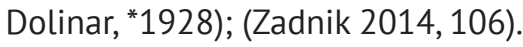

- 2. maja 1945 so nas iz lagerja izpustili domov z dovoljenjem za vožnjo z vlakom - najprej so spustili tiste z majhnimi otroki in s tem si je lagerfirer tudi rešil glavo (Alojz Pintar, ${ }^{* 1935) ; ~(Z a d n i k ~ 2014, ~ 119) . ~}$

- Pozno zvečer smo prišli v Freilassing, nekaj kilometrov pred Salzburg. Na neki kmetiji sta ata in Krašovec z vozov, ki so stali pod napuščem, podrgnila razbito opeko, ki je zaradi bombardiranja padla $\mathrm{s}$ strehe. Na vozovih smo si potem »postlali« in utrujeni zaspali do jutra. Zjutraj nas je prebudil gospodar. Po kratkem razgovoru nam je dovolil, da smo počitek nadaljevali v hlevu na senu. Bilo je veliko topleje, čeprav se je skozi razbito streho videlo nebo. Kasneje so gospodarja prosili, če bi nam lahko nekaj skuhali, saj že par dni nismo pojedli nič toplega. Imeli smo tudi nekaj mark, s katerimi smo želeli poravnati račun. Tako sem prvič po tistem, kar so nas selili, zopet dobil toplega mleka, v katerega sem podrobil posušen kruh, ki sem ga nosil v nahrbtniku. Mislim, da smo prespali še eno noč, da smo se spočili. [...] Do Salzburga nas je naslednji dan zjutraj (29. aprila?) gospodar odpeljal kar na vozu, vendar samo do predmestja (Peter Gortnar, ${ }^{* 1938) ; ~(Z a d n i k ~}$ 2014, 368-369).

Korektnost in dostojno ravnanje pri odpustu, spoštljivost na poti in še marsikaj drugega je ostalo v spominu.

b) na domačih tleh

- Decembra leta 1942 so naju z mamo odpeljali v Gonars v Italijo. Doma $v$ Ljubljani so se medtem ženske zbirale, protestirale in zahtevale, da iz taborišča spustijo ženske z otroki. In res so dosegle, da so nas v aprilu 1943 izpustili domov. Ko so nas pripeljali v Ljubljano, je bilo tam veliko veselja; pogostili so nas s čajem, pecivom, pela se je internacionala. Skratka, navdušenje je bilo veliko (Angela Tratnjek, "1940); (Zadnik 2014, 181). 
- Od prvega bega dalje je v meni ves čas tlela želja, da bi ušli, in s tem sem navduševala mamo. In jo tudi navdušila. [...] Mi smo pot začeli peš $v$ Wiechsu, tj. $30 \mathrm{~km}$ severno od Dachaua. [...] Pili smo vodo, kjer smo jo le dobili. Neka gospa nam je dala tudi malo mleka za najmlajšo. Imeli smo tudi srečo, da je prišel neki kamion in nas nekaj kilometrov peljal. Nato smo spet pešačili in še eno noč prespali v gozdu. Končno smo tretji večer le prispeli do Münchna, ki je bil ves zbombardiran. [...] Denar za karte sem zaslužila v mestni pralnici. Peljali smo se do Salzburga, tam smo spet kupile karte do Linza in nato do Jesenic in Škofje Loke. Mama je z manjšimi otroki ostala $v$ Škofji Loki pri znancih, tri sestre (Kristina, Darinka in jaz) pa smo jo bose peš mahnile s Trate proti Podlonku. Na Praprotnu nas je ustavila straža, ker je bila že policijska ura, vendar smo se vojakom očitno zasmilile in so rekli, naj hodimo bolj za krajem (Pavla Tolar, *1926); (Zadnik 2014, 269-270).

- Malo pred kapitulacijo je meni in štirim ujetnicam uspelo pobegniti. Dolga je bila pot proti domovini. 23. aprila 1945 smo prišle domov. $\vee$ Šentvidu so nas ujeli, ker nas je ena prijavila. Komandir postaje milice je bil dober človek in nas je spustil ter rekel, naj se držimo doma (Marija Brišar, "1926); (Zadnik 2014, 191).

- Na Jesenice oziroma v svojo domovino smo prispeli 2. maja 1945. Tam so nas domačini toplo sprejeli, kljub nemškim vojakom, ki so bili takrat še v Sloveniji. Odpeljali so nas v tamkajšnjo bolnico, kjer smo se umili in odpočili, tudi s hrano so nas okrepčali (Ciril Benedičič, *1928); (Zadnik 2014, 228).

- Končno smo se četrto noč z vlakom pripeljali na Jesenice. Tam so nas pričakali domačini in nas odpeljali $\mathbf{k}$ sebi domov. Pri njih smo prespali. Drugi dan smo nadaljevali pot proti domu (Vinko Markelj, $\left.{ }^{*} 1927\right)$; (Zadnik 2014, 252).

- Peti dan potovanja (30. aprila) zgodaj zvečer smo se skozi karavanški tunel pripeljali na Jesenice. Spominjam se, da je snežilo, kolikor je moglo. Ves čas potovanja smo imeli suho vreme. Jeseničani so bili takrat že organizirani in so za vračajoče izseljence pripravili sprejem. $\mathrm{Na}$ (razbiti) železniški postaji so izseljence razdelili po hišah Jeseničanov. Tako smo dobili toplo hrano in posteljo. Z vso kramo vred smo odšli z nekom od domačinov, ki nas je bil pripravljen prenočiti. Seveda so se družine razdelile, saj ni bilo mogoče pričakovati, da bi ena družina lahko prenočila po osem ali deset ljudi skupaj. Spominjam se, da smo slekli premočene obleke, dobili smo toplo hrano in svežo posteljo (Peter Gortnar, *1938); (Zadnik 2014, 369-370).

- Po naporni in seveda nevarni vožnji med vagoni smo prispeli na naše Jesenice. Tu so nas neznani ljudje nadvse prisrčno sprejeli. Peljali so nas na svoje domove $k$ počitku in po vseh svojih močeh postregli. Nas je sprejela neka zelo prijazna gospa. Mojo pozornost je takoj pritegnila kokoška, ki je vodila male kepice, piščančke po dvorišču (Minka Markelj, ${ }^{* 1940) ; ~(Z a d n i k ~ 2014, ~ 280) . ~}$ 
- Z bratom sva se nato odpeljala do Lesc in tam izstopila z vlaka ter pot nadaljevala peš čez Kropo. [...] V Kamni Gorici pa naju je ujela noč, zato sva se odločila poiskati prenočišče. Imela sva veliko srečo, da sva ga našla pri dobri družini, ki naju je tisto noč skrila. [...] Pot sva nadaljevala proti Podblici, kjer sva imela teto. Ker je ni bilo doma, naju je zelo gostoljubno sprejel njen mož, nama pripravil odlično kosilo in ponudil prenočišče (Justina Benedičič, ${ }^{* 1922) ; ~(Z a d n i k ~ 2014, ~ 272) . ~}$

- Končno je prišlo poletje 1945. To je bil čas vrnitve domov [iz Burghausena]. Brat, jaz in mama smo hodili kar peš, brez obutve in oblačil, iz taborišča proti Škofji Loki. Hodili smo 14 dni. V Škofji Loki smo se spet ločili. Mama je ostala pri »Otet«. [...] Dobili smo prve pakete Rdečega križa, da smo imeli nekaj hrane in obleke, saj smo tako lažje premagali težko pot, ki smo jo imeli pred seboj. Dohitel nas je konjenik z vozom, pripadnik bele garde, ki ni vedel, od kje izviramo. Mati naju je dala na voz in mu rekla, naj naju odpelje $\mathbf{v}$ Gorenjo vas. Ko smo se med potjo ustavili pri Frlc, so ga opozorili, naj se obrne in zbeži na Koroško. Naju je pustil na kmetiji, sam pa se je obrnil in odšel za njimi. Pozno ponoči naju je dohitela tudi mati in tisto noč smo tam prenočili. [...] Med potjo smo izgubili nekaj osebnih predmetov, tako da smo imeli le žlice, ki smo jih prinesli iz taborišča. Z njimi jem še danes, čeprav je od takrat preteklo skoraj 70 let. Svojci so nam pomagali, da smo se počasi spet postavili na noge (Jakob Rihtaršič, ${ }^{* 1941) ; ~(Z a d n i k ~ 2014, ~ 223) . ~}$

- Z vlakom smo se v Brežice vrnili 18. avgusta leta 1945. Neki sosed je s konjem in lojtrnikom na postajo prišel iskat sorodnike, in ker jih na tistem transportu ni bilo je domov odpeljal našo družino. [...] Zjutraj smo se zavedli realnosti - hrane nikjer, orodja nikjer. Kaj bomo jedli in kako bomo delali? Dobri sosedje, ki so bili doma že pred nami, so nam prinesli nekaj krompirja in fižola, pa tudi nekaj orodja (Marija Kožuh, *1933); (Zadnik 2014, 92).

- Vračali smo čez Tirolsko, skozi nešteto tunelov in čez nešteto mostov. [...] V Zidanem Mostu nas je že čakal voznik Mirko s konjsko vprego in sosedovim vozom lojtrnikom. Srečanje po dolgem času je bilo res veselo. Ko smo prispeli na Pristavo, tako se imenuje naša domačija, so nas sosedje pogostili $z$ obaro in ajdovimi žganci. Bilo je nepozabno! (Stanislav Ferle, *1938); (Zadnik 2014, 143-144).

- Domov smo se vrnili šele jeseni, 8. septembra 1945. Tam smo našli opustošeno domačijo. V njej so bili med vojno naseljeni Kočevarji - kočevski Nemci. [...] Vsi smo bili lačni, vsega je primanjkovalo, novi oblastniki pa so se prekmalu začeli obnašati kot novi gospodarji. Uvedli so obvezno oddajo (Stanislav Ferle, $\left.{ }^{*} 1938\right)$; (Zadnik 2014, 143-144).

- Pepevnakova mama, tako smo ji pravili, je bila zelo dobra, res kot mama. Dovolila je, da sem lahko sama šla $\mathbf{v}$ njihovo shrambo in se najedla, če sem bila lačna (Marija Kožuh, *1933); (Zadnik 2014, 93).

Kaj vse je doživela železniška postaja na Jesenicah. Radost ob vračanju izgnancev in istočasno grozo vračanja domobrancev. 


\section{Vrednote}

Medtem ko so v prejšnjem razdelku slovenske izgnance na sever in na jug združevali četudi le hipna prijaznost, sočutje in ponavljajoča se dobrota ljudi, s katerimi so se po sili razmer srečali in med katere so prišli, tukajšnji razdelek ozavešča zelo pomembno razliko med njimi.

Pri izgnancih v Srbijo se vprašanje jezika sploh ne pojavlja, saj so se zaradi pripadnosti obeh jezikov isti jezikovni skupini pogojno mogli sporazumevati tudi vsak s svojim jezikom, sploh pa so se Slovenci seznanjali s srbskim (srbohrvaškim) jezikom v tedanji ljudski šoli.

Velike težave pa so vsaj na začetku nastajale pri izgnancih $v$ nacistično Nemčijo, saj so bili med njimi redki, ki so obvladali nemščino. Tistim otrokom, ki se v slovenskih šolah še niti pisati niso naučili, pa je vsiljeni jezik tujega okolja postajal vedno bolj domač, saj pod stalnim nadzorom okupatorja ni bilo veliko možnosti za sproščen pogovor $v$ materinščini.

Razlika med slovenskimi izgnanci v Srbijo in Nemčijo je druge narave. V Srbiji so bili razpršeni, zato ni bilo možnosti in najbrž niti volje za organizirano druženje, saj jim je skrb za vsakdanje preživetje jemala vse moči.

V Nemčiji pa so družine ali njihovi različni člani prebivali bolj na tesno (na kar nakazuje že samo ime: »koncentracijska taborišča), zato ni bilo težko najti nekaj ubranih glasov in si v pesmi dati duška. Tudi poslušalcem je domača pesem blažila domotožje, naklonjenost tujih pa je bila eden od izrazov dobrote in sočutja.

Kadar je bilo treba peti na ukaz, so se čutili pevci ponižane, pesem pa je izgubila dostojanstvo kulturnega užitka.

\section{Jezik}

- Dnevi v izgnanstvu so bili dolgi in mračni. Delali smo cele dneve in tuji jezik nam je povzročal velike težave. Sčasoma smo se govorice priučili, vendar nismo pokazali, da jo obvladamo. To je bil dober izgovor, da kakšnega naročila nismo pravilno razumeli. Pri tolmačenju nam je bila v veliko pomoč starejša gospa, ki me je ob neki neprevidni izjavi rešila pred šefom. Na njegovo vprašanje, kaj bi naredil, če zmagajo Nemci, sem pogumno odgovoril, da bi Nemcem kar glave porezal. Šlo je za las, da me ni hudo kaznoval; gospa me je rešila, češ, da otrok pač ne ve, kaj govori, in da slabo razume tujo govorico (Aleksander Pivk, *1928); (Zadnik 2014, 194).

- Taborišče Dachau. Omenim naj le še srečanje z dr. Jakobom Šolarjem, svojim gimnazijskim profesorjem za slovenščino in francoščino. V taborišče je prišel kmalu po kapitulaciji Italije. Nikakor se nisem mogel sprijazniti s tem, da bi ga tikal in da bi svojemu spoštovanemu profesorju rekel kar preprosto Jaka. S pomočjo drugih Slovencev sem mu nekje organiziral za silo še uporabne civilne čevlje, saj je bil v lesenih 
»pantofilih« še bolj neroden kot jaz. V pogovorih nam je zaupal, da bo po vojni spisal slovensko slovnico, ki se bo brala kot pesem. Nekoč mi je pripovedoval, da ga je v Ljubljani zasliševal človek, ki je sedel za zaveso, tako da se nista videla. In ta zasliševalec ga je nekoč vprašal: »Gospod profesor, ali morda poznate dr. Janka Šmida iz Železnikov?« Vprašal me je, ali je morda meni, ki sem iz Železnikov, to ime kaj znano. Po njegovem naglasu je sklepal, da je najbrž iz Železnikov. Rekel sem mu, da človeka z imenom Janko Šmid poznam, vendar ta človek - kolikor vem - ni doktor. Je pa pred vojno študiral v Ljubljani in je verjetno $v$ Ljubljani ostal tudi med okupacijo (Tone Gortnar, *1922); (Zadnik 2014, 341).

- Teta Fani mi je povedala zanimiv utrinek iz izgnanstva. Ker nismo živeli v istem kraju - ona je bivala v Schwarzwaldu, naša družina pa v Baden-Württembergu - nas je ob priliki obiskala. Ob tem je bila presenečena, ko je videla, da se $\mathbf{z}$ dve leti mlajšim bratom Jožetom med igro pogovarjava nemško. Sam sem bil ob izgonu star slaba štiri leta, brat pa je komaj dopolnil dve leti in je znal prej govoriti v tujem kot pa v materinem jeziku. Starši so bili čez dan na prisilnem delu, otroci pa v vrtcu, v Kindersgartnu, kjer se je govorilo samo nemško. Vzgojiteljice so bile zelo stroge in same zaprisežene Nemke (Stanislav Ferle, ${ }^{* 1938) ; ~}$ (Zadnik 2014, 141).

- V Herbolzheimu smo stanovali v zasebnem stanovanju pri starejši gospe, seveda je bilo zelo skromno in v treh prostorih. [...] Ko so Nemci že slutili, da bodo izgubili vojno, je ena od sosed, s katero smo se poznali zaradi otrok, staršem naročila, da se morajo tudi po vrnitvi domov z menoj in mojim bratom občasno pogovarjati nemško, da ne bova pozabila jezika (Stanislav Ferle, ${ }^{* 1938) ; ~(Z a d n i k ~ 2014, ~ 142) . ~}$

- Naš dom je bil eno samo pogorišče. [...] Zame pa se je začela nepredvidena težava. Govorila sem gladko nemško, bolje kot po naše. Naša vas je bila zelo partizanska in tako so bili naravnani tudi otroci. Čim sem spregovorila po nemško, sem jih dobila po ustih. Domačim nisem upala potožiti, prepričana, da delam sila narobe, kadar sem po nemško spregovorila. Preden so naši ugotovili, kaj se mi dogaja, sem jih že nič koliko dobila po ustih (Minka Markelj, *1940); (Zadnik 2014, 280-281).

- Iz tega jesenskega časa mi je ostal v spominu še en zanimiv dogodek. Bil je pozen jesenski večer. Z bratom Jožetom sva bila na topli kmečki peči, ko je nekdo močno potrkal na hišna vrata. Brat Jože, še nevajen slovenske govorice, se je glasno oglasil: »Herein« - naprej. Vstopila sta dva oborožena partizana, oznovca, in nastala je zmeda, saj sta hotela vedeti, kdo je tisti, ki je tako pozdravil. Starši in ostali domači so bili zbrani za mizo in so le stežka dopovedali prišlekoma, od kod nemška govorica. Pogledala sta celo v kamro, če se v njej kdo skriva! Po hišah sta izvajala preiskavo zaradi raznih domnevnih skrivačev. K sreči se je vse dobro končalo (Stanislav Ferle, $\left.{ }^{*} 1938\right)$; (Zadnik 2014, 144). 
- Burghausen: Izgnanci smo živeli v treh stavbah bivšega samostana. Na koncu teh stavb je bila cerkev, ki stoji še danes. V njej smo imeli vsako nedeljo sv. mašo $\mathbf{v}$ slovenskem jeziku, in tudi peli so slovenski pevci iz lagerja (Ciril Benedičič, ${ }^{* 1928) ; ~(Z a d n i k ~ 2014, ~ 226) . ~}$

\section{Pesem}

- Izgnanci so tudi vestno hodili k maši v Lippertskirchen. Mladina se je zbirala in zbliževala na gričku nad lagerjem (domom izgnancev). Med izgnanci je bilo veliko odličnih pevcev. Ko srce preveva otožnost, pesem še bolj milo in lepo zveni. Tem prelepim zvokom se še strogi lagerfirer ni mogel upreti in nam zato ni branil petja. Toda slovenska uporniška duša ne more iz svoje kože. Tudi za ceno kazni ne. Enkrat so udarno zapeli "Slovenci kremeniti le stopimo v korak» in takrat je lagerfirer prihrumel penast od jeze. Sledila je prepoved druženja, petja in celo obiskovanja cerkve. (Minka Markelj, ${ }^{* 1940) ; ~(Z a d n i k ~ 2014, ~ 275) . ~}$

- Kar se verske oskrbe tiče, so lahko izseljenci hodili k nedeljskim mašam k nunam, v kapelo, ki je stala blizu hotela Diem, ali pa bolj daleč, v cerkev v Lippertskirchen. Ali je obstajalo kakšno določeno zaporedje maševanja ali pa je bila odločitev, kam k maši, odvisna od drugih dejavnikov, ne vem. Prav tako ne vem, ali se je hodilo k maši vsako nedeljo ali pa samo občasno. Bila je pa navada, da so po končanem obredu izseljenci ostali in peli. Menda so petje tudi domačini radi poslušali. Sam se spominjam samo maše v kapeli. Molilo in pelo se je večinoma ob Marijinem kipcu za lagerjem, kot sem že omenil. Za šmarnice so dekleta nabrala pomladanskega cvetja in kipec primerno okrasila. Gotovo pa se je po sobah v krogu družine veliko molilo. (Peter Gortnar, $\left.{ }^{*} 1938\right)$; (Zadnik 2014, 377).

- Iz Begunj so me dne 1. novembra 1941 odpeljali v Celovec na Landesgericht. Tudi tam so bili zapori prenatrpani. Srečal sem se s prvimi Čehi.Z menoj je bil tudi neki Rus Gerasimov. V spominu mi je ostalo, kot da je bil človek filma, literat, gledališki umetnik ali nekaj podobnega. V isti sobi je bil tudi koroški Slovenec Foltej Hartman iz Škocjana na Koroškem, ki je bil kasneje v Dachauu pevovodja slovenskega pevskega zbora (Stanonik 1993, 69-77).

- Ena izmed kazni je bila kazenski eksercir. Tega so uporabljali, če blok ali komanda ni korakala kot je treba, ali na povelje »Ein Lied« ni bilo takoj pesmi iz vseh grl. Tak eksercir sem doživel kmalu po prihodu. Naš 15. blok se je vračal $z$ dela in ni takoj ujel prave pesmi. $V$ vrstah, kakor smo korakali, smo morali tekati, se valjati, plaziti po komolcih, vstajati, spet tekati in spet padati, z obeh strani pa esesovci s palicami in bikovkami, ki so neusmiljeno pretepali, če so se vrste zmešale ali če je kdo ušel iz nje. [...] Eksercir je trajal dve uri, to je bila norma. Na smrt izmučeni smo se privlekli na blok, med potjo pa peli, kar smo mogli glasno. Pogled na čredo izmučenih in zmrcvarjenih ljudi, ki pojejo in 
korakajo v taktu pesmi, je bil kaj klavrn. Nemci so si znali izmišljati naravnost fantastične stvari, da so čim bolj mučili in poniževali ljudi in njihovo človeško dostojanstvo (Tone Gortnar, *1922); (Zadnik 2014, 307).

- Feilnbach: Mislim, da je bila skoraj v vsaki sobi lagerja vsaj ena slika, ki so jo stanovalci kupili in jo obesili na steno ali postavili na omaro. V parku je stal tudi manjši Marijin kip. Pri kipu Marije so bile organizirane šmarnice za izseljence. Tu se je predvsem pelo (Marija pomagaj nam vojskini čas ...), molile so se litanije in rožni venec v slovenskem jeziku. Kdo je dal pobudo za to oziroma ali je bilo to namerno organizirano, ne vem. Popolnoma mogoče pa je, da je do shajanja izseljencev prihajalo spontano. Zvečer, ko so se starejši vrnili z dela po bližnjih krajih in iz tovarn, je bil park primeren in prijeten prostor za shajanje mladih in starih. Ker se je tudi sicer mnogo pelo (trije Slovenci, kor!), ni nič čudnega, če se je poleg cerkvenih pelo tudi narodne pesmi. Od partizanskih pesmi se spominjam Na oknu glej ..., Kako je dolga, dolga pot ..., Po svetu jaz okrog blodim, od doma sem pregnan ..., Počiva jezero v tihoti ..., Stoji tam v gori partizan ... Kdaj in kako so prišle melodije in besedilo $\mathbf{v}$ lager, se ne morem spomniti. Vsekakor smo se tu shajali in predvsem otroci s starši, mladina je zahajala drugam (Peter Gortnar, *1938); (Zadnik 2014, 355).

- Prostega časa je bilo malo. Ko je kdo dopolnil 15 let, je bil razporejen na delo. Delavci so $v$ tovarnah ob sobotah delali samo izjemoma. Tisti, ki so delali po kmetijah ali služili pri zasebnikih, so mnogokrat morali delati tudi ob nedeljah. Drugače pa so bili ob nedeljah in praznikih prosti. Tisti, ki so se spoprijateljili, so se zbirali v skupine, kjer so obujali spomine, pripovedovali o domu in reševali uganke, igrali kakšne igre, mnogokrat in veliko peli, »prerokovali« o poteku vojne, njenem koncu in kako bo ob vrnitvi vse drugače, lepše, boljše, čeprav smo mnogi vedeli, da je domačija porušena, požgana in izropana, da se marsikdo ne bo vrnil itd. Mislim pa, da je večina izseljencev mislila, da slabše, kot je v tujini, ne more biti. Verjetno pa je bilo kar precej družin v domovini, ki so živeli objektivno slabše kot mi v izseljeniških lagerjih. »Boljše« je bilo samo to, da so bili doma (Peter Gortnar, *1938); (Zadnik 2014, 377-378).

- Dr. Milan Gregorčič je na gestapo poslal prošnjo za vrnitev Antonije iz Nemčije, ki je pri nemških oblasteh naletela na razumevanje. Tako smo dobili dekret za vrnitev v rodni kraj. Za veseljem pride tudi nekaj bridkosti. Težko je bilo slovo od sotrpinov v lagerju. Omenjena vzgojiteljica Pavla Kump je v majhni sobici, ki je imela najboljšo povezavo s hodnikom, organizirala poslovilni trenutek s pesmijo Zaplula je barčica moja. Ta pesem mi je ostala v spominu kot nekakšna poslovilna himna. Mama jih je spodbujala z besedami: »Tudi vi pridete za nami, saj to ne more dolgo trajati« (Alojz Filipič, $\left.{ }^{*} 1938\right)$; (Zadnik 2014, 219). 
- Prišel je neskončno zaželeni dan - 10. julija 1945 smo končno odšli proti Sloveniji. [...] Slovenci smo v hotelu Kren Čačak za domačine priredili »oproštajno veče«, poslovilno slovesnost s programskim delom in koncertom. Izseljenci so si v Čačku prirejali pevske vaje in peli ob vsaki priložnosti. Dva Slovenca - zbor. Poslovili smo se od dobrih ljudi in šli s »punklni« nazaj. Zelo smo se veselili in bilo smo presrečni (Breda Blaznik, *1928); (Zadnik 2014, 176).

- Začel sem hoditi tudi v šolo. V razredu ni bilo klopi in nismo imeli nobenih knjig in zvezkov. Sedeli smo na tleh in učiteljica nam je pripovedovala razne zgodbe ali pa brala pravljice iz knjige. Učili smo se partizanskih pesmi in ob lepem vremenu šli na »izlet« (Peter Gortnar, *1938); (Zadnik 2014, 373).

\section{Sklep}

Navedki se nanašajo na temeljni sestavini človekove eksistence, okrog katerih se je vrtela skrb staršev v neznanem okolju: bivališče in hrana. Otrokom je bila prihranjena skrb zanju.

Tako je lahko eden od njih zapisal: »Kolikor se spomnim, se mi kot otroku ni zdelo nič hudega. Stanovali smo pri kmetih. Bili so veseli, da smo pomagali. Ata je bil izučen krojač in je kaj tudi zašil. Na kmetiji je lahko opravljal težja dela, otroci pa smo delali v sadovnjaku, pobirali krompir, okopavali vinograd. Tako da so nas imeli kar radi. Sadja je bilo ogromno. Imeli so slive, hruške. Lačni nismo bili« (Jernej Gortnar, *1935); (Zadnik 2014, 245). Tukaj se tudi lepo vidi povezanost med duhovno, družbeno in materialno kulturo. Če bi ne bilo duhovne vrednote: Kakor želiš, da drugi tebi stori, stori ti drugemu (prim. Mt, 7,12), ki zapoveduje pomagati drugemu, je vprašanje, če bi prišlo do tako pomembne izjave, ki se nanaša na fizični obstoj.

Tudi slovenski pregovor: »Ljubezen gre skozi želodec« so prav otroci najbolj konkretno doživljali: jabolko, krompirček, češnja so bile dobrote, ki jih do starosti niso pozabili. Bile pa so še druge: na silo potlačena tableta $v$ grlo za zdravje, dostojno oblačilo ob vrnitvi v domovino, vpis delovne dobe $v$ delavsko knjižico, pa pripomočki za bivanje - postelja, posoda za kuhanje, pogled $v$ oči, ponudba prenočišča.

Na družbeni ravni se razlika med okoliščinami izgnanstva v Nemčiji in Srbiji kaže v tem, da je bila drža do izgnancev v okupatorski državi pogojena tudi politično, zato je bila tam dobrota marsikdaj kaznovana. Glede na nekdanjo skupno državo Jugoslavijo so bili oboji, Slovenci in Srbi, na isti ravni - okupirani! Zato se da razumeti srbsko pomoč izgnanim Slovencem ne zgolj kot solidarnost človeku v stiski, temveč tudi kot način odpora proti nemškemu okupatorju. 
Literatura

Biček, Slava. 2014. »72 let izgona Slovencev in 22. obletnica delovanja Društva izgnancev Slovenije 1941-1945«.V Naši spomini, Zbornik izgnancev [...], ur. Rudi Zadnik, 12-15. Škofja Loka : Območna organizacija Škofja Loka : Društvo izgnancev Slovenije 1941-1945.

Demšar, Marija. 2014. Pisma iz Šida. Šid : Galerija slika »Sava Šumanović«.

Fabjančič, Gustav. 1959. Pisma iz izgnanstva. Celje : Mohorjeva družba.

Ferenc, Tone. 1986. Nacistična raznarodovalna politika v Sloveniji v letih 1941 1945. Maribor : Obzorja, Maribor.

Gortnar, Tone. 2014. "Skozi nemške zapore in taborišče«. V Naši spomini, Zbornik izgnancev [...], ur. Rudi Zadnik, 292-342. Škofja Loka : Območna organizacija Škofja Loka: Društvo izgnancev Slovenije 1941-1945.

Košenina, Saša. 2014. »Nacistična raznarodovalna politika med drugo svetovno vojno: množične deportacije iz Gorenjske«. V Naši spomini, Zbornik izgnancev [...], ur. Rudi Zadnik, 16-22. Škofja Loka : Območna organizacija Škofja Loka : Društvo izgnancev Slovenije 1941-1945.

Repe, Božo. 2015. S puško in knjigo, Narodnoosvobodilni boj slovenskega naroda 1941-1945. Ljubljana : Cankarjeva založba.

Stanonik, Marija. 1993a. »Na tleh leže slovenstva stebri stari« (Poezija konteksta II). Borec : revija za zgodovino, literaturo in antropologijo 45 (8-10): 946-952.

Stanonik, Marija. 1993b. Slovenska pesem v Dachauu. Borec : revija za zgodovino, literaturo in antropologijo 30 (11): 623-629.

Stanonik, Marija. 2008. Etnologija u pismima i slikama. Beograd : Etnografski institut SANU.

Zadnik, Rudi (ur.). 2014. Naši spomini, Zbornik izgnancev, beguncev in pregnancev iz občin Gorenja vas - Poljane, Škofja Loka, Železniki in Žiri. Škofja Loka : Območna organizacija Škofja Loka : Društvo izgnancev Slovenije 1941-1945. 
Marija Stanonik

ZRC SAZU

Institut za slovenačku etnologiju

Ljubljana, Slovenija

marija.stanonik@zrc-sazu.si

\section{NA DOBROTI SVET OPSTAJE: ISKUSTVA SLOVENAČKIH IZGNANIKA POSLATIH U OKUPIRANU SRBIJU I NACISTIČKU NEMAČKU TOKOM DRUGOG SVETSKOG RATA}

Za ratna vremena uglavnom se vezuju samo teške i loše stvari. Ovaj pregled se bavi malim gestovima dobrote i ljubaznosti, koje su autori sećanja doživeli kao deca i zapisali ih sedamdeset godina kasnije.

Ključne reči: Drugi svetski rat, izgnanici, deca, Srbija, Nemačka - Treći rajh, Društvo izgnanika Slovenije 1941-1945

Marija Stanonik

SRC SASA

The Institute of Slovenian Ethnology

Ljubljana, Slovenia

marija.stanonik@zrc-sazu.si

KINDNESS HOLDS THE WORLD TOGETHER: THE EXPERIENCE OF SLOVENIAN INTERNEES IN THE OCCUPIED SERBIA AND NAZI GERMANY DURING WORLD WAR II

Wartime is usually associated with hardship and bad things. This review deals with the small acts of kindness and consideration that the authors of reminiscences experienced as children, to write down the memory of them seventy years later.

Keywords: World War II, internees, children, Serbia, Germany - Third Reich, Association of the Internees of Slovenia 1941-1945 